\title{
On properties of harmonic intervals: Sonance, acousticity, phonism
}

\author{
Miroslav Kirilov Nedyalkov \\ Pedagogical Faculty, Konstantin Preslavsky University, Shumen, Bulgaria
}

Email address:

mnedyalkov@mail.bg

\section{To cite this article:}

Miroslav Kirilov Nedyalkov. On Properties of Harmonic Intervals: Sonance, Acousticity, Phonism. International Journal of Literature and Arts. Special Issue: Musical Theory, Psychology and Pedagogy. Vol. 2, No. 5-1, 2014, pp. 84-87. doi: 10.11648/j.ijla.s.2014020501.24

\begin{abstract}
This research synthesizes concepts derived from previous studies of the author regarding sonance [1], acousticity and phonism [2] that affect the properties of harmonic intervals and vertical sound complexes. The classification of texture "with and without an expressed bass" [3], which had its place in the textbook that was published later, is important in the context as well [4]. The dual nature of the fourth and tritone, and the significant differences in the perception of other intervals, depending on their placement in musical space, inevitably raise the question - can all these phenomena be explained with the approved terms consonance and dissonance. The physical basis of all vertical sound complexes is the harmonic series, but the plays of the author,' indicate how this order forms the concept of sonance and acousticity. The definition of these terms is only the beginning of future research on phonetic properties of harmonic intervals and harmonies to achieve a qualitatively new classification of acoustic characteristics.
\end{abstract}

Keywords: Harmonic Interval, Sonance, Consonance, Dissonance, Acousticity, Phonism

The subject of properties of harmonic intervals seems to have used all possible arguments with the myriad theories dedicated to sonance and is reduced only to the categories consonance and dissonance. The phonic characteristics of intervals and chords have a multitude of nuances, upon which the question raises - can they be explained solely by the notions consonance and dissonance. The theories of sonance cannot explain the double nature of the fourth, for example, once taken for a consonance, sometimes thought to be a dissonance. The same can be noticed regarding the tritone. Hindemith regards it as "the tensest dissonance" [5], but this is valid if only it is formed in relation with the bass. In the upper layers of the texture the interval sounding is different. An interesting phenomenon is observed in sol-fa lessons while students try to guess intervals...they distinguish with difficulty the phonism of the tritone from that of the minor sixth. When making such mistakes, it is logical that a question raises - what kind of a dissonance is the tritone if an even immature musical ear takes it for a consonance interval. Similar thoughts can provoke the seventh as well, the minor one above all, which in some tetrachords shades the faults of the common triads from acoustic point of view despite considering it to be a dissonance. In fact, such strange metamorphoses can be found more or less in almost every interval. Having in mind the latter we can conclude that a universal formulation of an interval or a chord cannot exist. Nuances and contradictions in their phonic characteristics depend, more or less, on their arrangement in the music space and, of course, on the procedure nature of functionality. The latter factor will not be the subject of this study because it needs a deep research and has to be a subject of a single science investigation.

Finding explanation of the above phenomena requires a broader insight into the matter, reaching above the well known ideas for consonance and dissonance and passing necessarily through the definition of the terms sonance, acousticity, phonism. They are found in many works of the musical science but their meaning is not clearly defined and can only be guessed. The harmonic series can serve for the physical basis for the three terms.

\section{Sonance}

Sonance "is a function of the acoustic basis of the sound matter and psychological factors related to the functional organization and adaptation of musical ear in evolutional 
processes of polyphonic thinking" [6]. This category suggests a fragmented approach and is based on separate segments (intervals) in the harmonic series, with the exclusion of the prime and the octave suggests exclusion of its basis (e.g. 1:2, 2:3, 3:4, 4:5, etc.). Sonance is invariably connected with the terms consonance and dissonance like two reciprocally connected opposites, analogous to light and shade in painting. Perception of consonance and dissonance has a relative character and has been developed during the ages in accordance with the evolution of composition techniques, the current musical system and the adaptation of the musical ear to all novelties.

An encyclopedic inquiry shows the existence of several theories: [7]

- The simple arithmetic proportion theory dates back to antiquity and is expressed in the proportion correspondence in the lower part of the harmonic series. Originally this theory stresses on four consonances the prime, the octave, the fifth and the fourth. In $12^{\text {th }}$ century the needs of polyphonic organization enforce a gradual change in the absolute quantity of thirds from the fifth system to values, close to those in the harmonic series. This suggests widening the sphere of consonances, which in $16^{\text {th }}$ century are approved finally to six with their generally adopted differentiation into perfect and imperfect.

- The theory of overtones $\left(17^{\text {th }}-18^{\text {th }}\right.$ century) confirms the established practice of harmonic division of the old theory.

- The oscillation theory $\left(19^{\text {th }}\right.$ century) explains the dissonance as the result between two oscillations with close but not identical frequency, while the consonance is a correlation where this oscillation is missing.

- The fusion theory from the end of $19^{\text {th }}$ century is based on a psychophysiological test, through which pereception of consonance is explained as a result of the fusion of two tones.

- The combination tones theory examines the phenomenon from the point of view of their compatibility and incompatibility in simultaneously sounding of the two tones.

- The two - term experiment theory from the first half of $20^{\text {th }}$ century directs to differentiated perception of interval tones.

- The theory of coincidence $\left(19^{\text {th }}-20^{\text {th }}\right.$ century) is based on the relationship of tones with the common pillar of the harmonic series. It Is presented as a coincidence of "objective" and "subjective" overtones and the degree of consonance according to this theory is defined by the simplicity or the combination of these coincidences. As a borderline between the consonance and the dissonance are mentioned ratios 6:7 and 7:8 and the following as such that the dissonance predominates.

- The multiple theory $\left(20^{\text {th }}\right.$ century) tries to realize a synthesis among all theories.

It is obvious that the mentioned theories ignore the functional organization as a factor, influencing the sonance stability of intervals. Since the end of the $19^{\text {th }}$ century scholars have begun to pay attention to this and gradually in musical theory the attitude has formed that dissonant are not only the seconds, the sevenths and the tritone, but also all augmented and diminished (double augmented and double diminished intervals respectively). The latter mentioned could not be identified as taken separately but only in relation with other tones and chords, i.e. in the context of functionality. Already Dryer, assuming that every dissonance has to become a consonance, includes in the table of dissonances also diminished and augmented intervals [8]. This thinking is shared by Sposobin (Способин) [9], Vahromeev (Вахромеев) [10], Krasinskaya - Utkin (Красинская-Уткин) [11], Gyulyanu - Yuskyanu [12], Hadzhiev (Хаджиев) [13], while Karastoyanov (Карастоянов) insists that the consonance and the dissonance of the perfect fourth and the two forms of the tritone are defined " in accordance with the case" [14]. Whether these scholars are right in their arguments is still unclear. Proof can be provided in both directions. If it is assumed later that harmonic intervals apart from sonance have other features as well, perhaps it would be more appropriate those, augmented and diminished, but containing a tone volume, equivalent to a consonance, to be just called unstable.

While examining the acoustic basis of sonance, we can note that the simplest and clearest theory of all is the one of the mathematical proportion, which gives an opportunity for arranging the intervals as a degree of sonance, according to their position in the harmonic series. The theory of coincidence is positive for the fact that defines the borderline between the consonance and the dissonance, which above all we owe to H. Husmann. It is yet necessary to be specified that the two ratios he mentions, representing that borderline, with their sensitive deviation from the equal temperament and the circle of fifths, are unused in the musical systems, based on the ratio tone - semitone.

Some scholars provoke interest by arguing that " there is a lack of absolute conception of the consonance and the dissonance" [15]. Yet, we can assume most scholars' beliefs about the borderline between the consonance and the dissonance in the zone of the seventh tone of the series. Thus all segments above it are defined as dissonant. It is clear that some intervals can easily be explained as neighboring tones of the series, while others (the tritone, the sixth and the seventh) are formed as non - neighboring tones of the series. This causes a number of difficulties in explaining their phonic nature. In fact, the sixths and the sevenths can be assumed as an inversion of the thirds and the seconds respectively, but the tritone is always formed between the non - neighboring fifth and seventh tone, i.e. it can be found in the directory of the consonances and borders with the one of the dissonances. Therefore in intermediate and high tessitura its sounding is assumed as " the closest to the consonance" [16]. In this case its adding to one of the two categories may only be a word play, as in the phrase of the half-full or half- empty glass, which in both cases contains 
the same liquid quantity.

The octave equivalence of tones is the occurrence on which the phonic similarity is based in the so called inversion of intervals and chords. This is the ratio 1: 2 and stresses the exceptional meaning of the second tone of the harmonic series, found an octave from the basis. For example, if the third $\mathrm{C}-\mathrm{E}$ sounds, the octave projection of $\mathrm{C}$ is heard at the same time as well, which is a sixth from E. Thus in inversion the musical ear registers similar phonic parameters, but as it will become clear later, they sometimes undergo essential changes in the inversion made that way.

The tritone and the perfect fourth cause the most striking contradiction among their different phonic behavior in the musical field, whose explanation is still not thorough, perhaps because harmonic intervals apart from sonance have another feature as well.

\section{Acousticity}

Acousticity is a feature of vertical sound complexes and depends on their degree of similarity with the overall configuration of the harmonic series and mainly of its basis (the first tone). Thus for centuries scholars have tried to find the explanation of the minor, which is based more on sonant than on an acoustic basis.

What meaning do sonant and acoustic features of harmonic intervals have in polyphonic music? This depends on the types of texture that can be divided mainly into two categories: "texture without an expressed bass" and "texture with an expressed bass" [17].

The texture without an expressed bass is in two, three sometimes in four voices, located in an intermediate and high tessitura, where the lowest voice has no function of a bass party. In vocal ensembles these are women's and children's choirs as well as some mixed formations with the participation of high and intermediate men's voices. Whether a given texture in intermediate or high pitch is without an expressed bass, can be defined easily by transposing it in a low tessitura. If the polyphony does not sound convincingly and the lowest voice has no characteristics of a bass party, then this is a texture without an expressed bass. Therefore, such texture type cannot exist in a low tessitura. Only sonant features of intervals are important in this type of texture forming.

A texture with an expressed bass contains four or more voices, rarely three, where the lowest one has the function of a bass party. If in a low tessitura there should not be a hesitation about the texture type, in intermediate and high ones such will appear. Here again, the test with the transposing in a low tessitura would help the truth to be found. Therefore, a party with a bass function can exist not only in a low but in an intermediate and a high tessitura as well. In this texture type the lowest voice in question acquires acoustic modality with the intervals which are formed in relation to the rest of the voices. The vertical stability of chords depend on the acousticity degree and the motives a bass tone to be chosen in a given moment, in accordance with the fact whether a harmonic perfection is needed, equilibrium, peace or the contrary non-equilibrium, tension, instability. With this feature, for example, the priority of the major third over the minor one, the priority of the major over the minor, respectively.

The sonant, as well as the acoustic feature of the interval depends on its place in the harmonic series. The specific character of defining the acousticity degree is whether the main tone of the interval coincides with the main tone of the harmonic series. And if in sonant features the ratios were 8between neighboring serial digits, then in this case the ratio will be to a single digit - one. Thus would look the table with the intervals, which are to be qualified as acoustic :

$1: 2$ perfect octave

$1: 3$ perfect fifth

$1: 5$ major third

1:7 minor seventh

1:9 major ninth

Their degree of acousticity would not be the same, for they are in different positions from the basis, accepted for one. In other words - the smaller the arithmetic fraction, the weaker the degree of acousticity. Influence over this feature of harmonic intervals should exert the harmonic series up to the eighth or the ninth tone. The following tones for obvious reasons have insignificant acoustic sounding. Even the seventh and especially the ninth one would display in full extent their acoustic nature. The reason for this is simple - in order to acquire maximum acoustic expression the intervals, shown in the table need to have tone volume corresponding to that in the harmonic series. Thus the fifth would manifest itself the most convincingly in the mode of a twelfth, a major third and a minor seventh as well, and need to be found more than two octaves, while the major ninth - more than three.

The question with the minor seventh is interesting. On one hand, the seventh is thought to be a dissonance, on the other hand - an acoustic interval. As a result, it should be understood that the dissonant tension of the interval in the chord cannot provide itself tone function in the traditional harmony but can serve as a stabilizer in the mentioned vertical. The dominant seventh chord, for example, sounds more harmoniously and proportionately than its inversions. As a proof we can point the fact that such an interval, formed toward the seventh tone, is used in organ's mixtures. It can be certainly specified that the impression of such organ melodiousness is not because of a dissonance or disharmony but just the opposite.

The question with the major ninth is similar. The dominant ninth chord, containing this interval in a maximum wide disposition, sounds brilliantly. It is also possible that the ninth is "a phonic nucleus" [18] of the tonic chord in the so called "complex tonics" [19] from the beginning of $20^{\text {th }}$ century.

\section{Phonism}

Phonism is the characteristic color of vertical sound complexes caused by the activity of their acoustic and 
sonant features. It is a broader term, encompassing the two features examined above. In other words, this is the characteristic sounding of the vertical constructions, often called harmonious color.

From the point of view of the polyphonic texture the following conclusion can be done:

Acousticity is important for bass party disposition, while sonance - for the rest of the voices. All these elements of the texture are united by phonism as a whole sound picture.

All this means that harmonic intervals possess not only sonant, but acoustic features as well, united by the idea of phonism.

In conclusion we should remind that acousticity should not be mixed with the comprehension of sonance as a quality of the interval, for these are different features. The feature acousticity of the interval inevitably influences chords and reasons for choosing the bass tone. Sixths and related to them major and minor hexachords, for example, are consonances, but in the polyphonic texture with an expressed bass they cannot be conclusive tonic constructions. Unlike them, the seventh and the ninth, can perform such function in the contents of the complex tonics.

It is thoroughly understandable that researches on acousticity of intervals and chords need to continue in order at least a categorization in acoustic signs to be reached. A subject of study will be the harmonic series as well as the polyphonic music during the centuries. The relation between the physical bases of the musical art and practice, born by the artistic intuition perhaps will be the key to the truth for a phenomenon, which the musical science has not explained yet.

\section{References}

[1] M. Nedyalkov, "Minor Tonalitas", University ed. "Bishop Konstantin Preslavsky”, 2009. М. Недялков, „Минорната тоникалност”, Университетско издателство „Епископ Константин Преславски", 2009.

[2] M. Nedyalkov, "To the question of the properties of harmonic intervals", in Innovation in Education, Shumen, 2013, pp. 182-186. М. Недялков, „Към въпроса за свойствата на хармоничните интервали", Иновации в образованието, Шумен, 2013, с. 182-186.

[3] M. Nedyalkov, "Modal harmony in the arrangement of Bulgarian folk music, in Musical horizonts vol. 8-9, Sofia,1996, pp. 1-36. М. Недялков, „Модалната хармония в обработката на българската народна музика", Музикални хоризонти, бр. 8-9. София, 1996, с. 1-36.

[4] M. Nedyalkov, "Foundation of modal harmony", University ed. "Bishop Konstantin Preslavsky", 2013. М. Недялков, „Основи на модалната хармония”, Университетско издателство „Епископ Константин Преславски”, 2013.

[5] U. Holopov, "Tasks in Harmony", Moskow, 1983, pp. 137. Ю. Холопов, „Задания по гармонии”, Москва, 1983, с. 137.

[6] M. Nedyalkov, "Minor Tonalitas", University ed. "Bishop Konstantin Preslavsky", 2009, pp. 98. М. Недялков, „Минорната тоникалност”, Университетско издателство „Епископ Константин Преславски”, 2009, с. 98.

[7] Das Grosse Lexikon der Musik, Bd 4, Herder, Frieburg, Basel, Wien, 1982, pp. 407-408.

[8] A. K. v. Dryer, "Elementary music theory. Experience a systematic exposition”, St. Petersburg, 1888, pp. 25-27. A. К. ф. Дрейерь, „Элементарная теория музыки. Опыт систематического изложения”, С.-Петербургь, 1888, с. 25-27.

[9] I. Sposobin, "Elementary music theory", Sofia, 1956, pp. 65-66. И. Способин, „Елементарна теория на музиката”. София, 1956, с. 65-66.

[10] V. Vahromeev, "Elementary music theory", Sofia, 1963, pp. 77. В. Вахромеев, „Елементарна теория на музиката”, София, 1963, с. 77.

[11] L. Krasinskaya, V. Utkin, "Elementary music theory", Moskow, 1965, pp. 102. Л. Красинская, В. Уткин, „Элементарная теория музыки”, Москва, 1965, с. 102.

[12] V. Gyulyanu, V. Yuskyanu, "Tratat de teorie a muzicii”, I si II part., Bucuresti, 1962, 171-174.

[13] P. Hadzhiev, "Elementary music theory", Sofia, 1974, pp. 105. П. Хаджиев, „Елементарна теория на музиката”, София, 1974, с. 105.

[14] A. Karastoyanov, "Elementary music theory", Sofia, 1946, pp. 52. А. Карастоянов, „Елементарна теория на музиката", София, 1946, с. 52.

[15] E. Toch, "The chaping forces in music". New York, 1948.

[16] M. Nedyalkov, "Minor Tonalitas", University ed. "Bishop Konstantin Preslavsky", 2009, pp. 96. М. Недялков, „Минорната тоникалност”, Университетско издателство „Епископ Константин Преславски”, 2009, с. 96.

[17] M. Nedyalkov, "Modal harmony in the arrangement of Bulgarian folk music, in Musical horizonts vol. 8-9, Sofia, 1996, pp. 10. М. Недялков, „Модалната хармония в обработката на българската народна музика”, Музикални хоризонти, бр. 8-9. София, 1996, с. 10.

[18] M. Nedyalkov, "Minor Tonalitas", University ed. "Bishop Konstantin Preslavsky”, 2009, pp. 90. М. Недялков, „Минорната тоникалност”, Университетско издателство „Епископ Константин Преславски”, 2009, с. 90.

[19] U. Holopov, "Tasks in Harmony", Moskow, 1983, pp. 84-85.Ю. Холопов, „Задания по гармонии”, Москва, 1983, c. $84-85$. 